Article

\title{
Image and Substance Failures in Regional Organisations: Causes, Consequences, Learning and Change?
}

\author{
Meng Hsuan Chou ${ }^{1, *}$, Michael Howlett ${ }^{2,3}$ and Kei Koga 4 \\ ${ }^{1}$ Public Policy and Global Affairs Programme, Nanyang Technological University, 637332 Singapore; \\ E-Mail: hsuan@cantab.net \\ ${ }^{2}$ Department of Political Science, Simon Fraser University, Burnaby, BC V5A 1S6, Canada; E-Mail: howlett@sfu.ca \\ ${ }^{3}$ Lee Kuan Yew School of Public Policy, National University of Singapore, 259771 Singapore \\ ${ }^{4}$ Public Policy and Global Affairs Programme, Nanyang Technological University, 637332 Singapore; \\ E-Mail: kkei@ntu.edu.sg \\ * Corresponding author
}

Submitted: 9 March 2016 | Accepted: 25 May 2016 | Published: 11 August 2016

\begin{abstract}
States often pool their sovereignty, capacity and resources to provide regionally specific public goods, such as security or trade rules, and regional organisations play important roles in international relations as institutions that attempt to secure peace and contribute to achieving other similar global policy goals. We observe failures occurring in these arrangements and activities in two areas: substance and image. To analytically account for this, we distinguish four modes of substance and image change and link these to specific types of failure and (lack of) learning. To empirically ground and test our assumptions, we examine instances of image failure in ASEAN (political/security policy) and substantive policy failure in EU labour migration policy. In so doing, this article contributes to several different fields of study and concepts that have hitherto rarely engaged with one another: analyses of policy failure from public policy, and regional integration concerns from area studies and international relations. We conclude with suggestions for ways forward to further analyse and understand failures at the international and supranational levels.
\end{abstract}

\section{Keywords}

image failure; institutional change; learning; policy failure; regional organisations; substantive failure

\section{Issue}

This article is part of the issue "Supranational Institutions and Governance in an Era of Uncertain Norms", edited by Russell Alan Williams (Memorial University, Canada) and Reeta Tremblay (University of Victoria, Canada).

(C) 2016 by the authors; licensee Cogitatio (Lisbon, Portugal). This article is licensed under a Creative Commons Attribution 4.0 International License (CC BY).

\section{Introduction: Failures in International \\ Cooperation-From the Spectacular to the Everyday}

Failures of organisations for beyond-the-state cooperation, including their demise, are prominent in world history. When the League of Nations failed to prevent the outbreak of World War II, for instance, it was considered to be malfunctioning and collapsed shortly after the war, dissolving itself in 1947. Similarly, external political shocks, such as the Sino-US rapprochement in 1972 and the conclusion of the Cold War in 1989, led some regional organisations, such as the Asia-Pacific Council and the Warsaw Pact Organisation to become dysfunctional or irrelevant, resulting in their rapid collapse. But not all international arrangements fail or fail so spectacularly and not all failures result in wholesale replacement of existing organisational arrangements. How these lesser failures occur, how they can be conceptualised, and what their occurrence foreshadows for regional arrangements are the subjects of this article.

Better understanding of the nature of failures at this level, the reasons for their variation, their conse- 
quences and what can be done about them, is critical for contemporary policy studies and international relations. Below we explore how policy failure can be defined, identified and, in turn, affect the existing set-up of regional organisations. Our framework for analysis combines several literatures which rarely speak to each other, but should: the literature on public policy (Bennett \& Howlett, 1991; Dunlop \& Radaelli, 2013; Howlett, 2012; Radaelli \& Dunlop, 2013), organisation studies (Dodgson, 1993; Etheredge \& Long, 1981; Etheredge \& Short, 1983; Shrivastava, 1983), and comparative politics (Mahoney \& Thelen, 2010; Streeck \& Thelen, 2005).

We see policy failure as generally related to the 'institutional design and capacity issues such as organizational and human-resource capability and competences' (Howlett, 2012, p. 546) and develop a model of failure types taking these factors into account. To empirically ground our assumptions and test this framework we examine two instances of policy failure in regional organisations: Association of South East Asian Nations (ASEAN) (political/security policy) and the European Union (EU) (labour migration). We then discuss the significance of our findings with respect to these different types of failures and policy learning.

\section{Studying Policy Failures in International Organisations: Definitions and Approaches}

The above observations raise several questions about failures, their consequences and learning in international and regional organisations which scholars of public policy and international relations have only begun to address. For instance, do all failures lead to sizeable policy change or to less dramatic reforms and tinkering with existing arrangements? Or do they sometimes lead to no action at all? And, related to these: why do some policy failures lead to organisational collapse, while others do not? To what extent do policy failures shape the design of international organisations? Is there a cycle of failure and learning involved in the everyday functioning of such organisations? And, if so, how do we first detect and then determine which 'failure-learning' mechanism is weak and which is robust?

\subsection{Defining Policy Failure}

Since an international organisation is essentially an embodiment of its member states' efforts to achieve an objective and to resolve broadly-defined policy problems or to project the image of collective will, its failure to do any or all of these actions would likely lead the organisation to restructure its efforts in order to increase effectiveness and avoid further organisational ineffectiveness without restructuring (Hulme \&
Hulme, 2012; Jachtenfuchs, 1996). ${ }^{1}$ Yet this perspective on organisational responses to failure is limiting and does not take into account the more subtle ways in which a policy or organisation can evolve. In addressing the questions about learning and failure at the international level set out above, it is important to first better conceptualise the possible empirical manifestations of policy failures in international organisations as well as their links to modes of institutional change, evaluation, and learning (Borrás \& Højlund, 2015; Stone, 1999, 2001; Thomas, 1999; Van der Knaap, 1995; Zarkin, 2008). A better theory and model would take into account the modes of organisational change which can occur and link these to specific mechanisms of reform or re-structuring such as policy learning or lessondrawing (Argyris \& Schön, 1978; Busenberg, 2001; Huber, 1991; Rose, 1993, 2005).

In this article we operationalise policy failure based on the relativistic concept of 'contra-policy success'. Simply put, as McConnell (2010) and others have argued, if a policy has not (yet) achieved its objective, it is regarded as a 'failure'. ${ }^{2}$ To be more precise and to add a clearer temporal aspect to this definition, we define policy failure as the failure to achieve previously established policy objective(s) within a specified time frame, often of at least a decade. This definition allows us to evaluate success or failure of policy implementation

\footnotetext{
${ }^{1}$ For consistency, we use the term 'organisation' throughout this article to refer to bureaucratic political entities. We focus on beyond-the-nation-state organisations and use 'international' to refer to multilateral inter-state cooperation and 'regional' to a form of international cooperation involving states sharing some geographical similarities. The regional organisations we examine are often considered institutions because they embody particular sets of rules and norms that characterise that inter-state cooperation. Following established literature in international relations and comparative politics, we see that institutions may endure while organisations collapse. We use the terms 'institutional' and 'institution' when engaging with these sets of literature on change and learning.

2 While academic definition remains contentious, Howlett (2012) identifies two mainstream definitions. One is relativistic. Since it is difficult to objectively identify 'success' and 'failure', this definition takes the position that the subjective assessment of a policy is inevitable, and, thus, depending on individual perspectives, a policy can be considered to have failed or succeeded. The other approach defines failure as anything opposite of policy success. The two definitions have their own merits, but also limitations. The former implicitly focuses on the consequence of policy implementation, while acknowledging that it is subjectively interpreted. As a result, policy failure may be defined in an arbitrary manner. The other definition is relatively objective because it focuses on the process of policy implementation; yet, such a dichotomy between success and failure will miss some nuanced interpretations of the implementation process, not to mention the possible causal relationship between policy outputs and policy outcomes. We therefore synthesise both definitions in our own.
} 
vis-à-vis the original policy objective(s) as a reference point, while setting a time frame around this assessment (Howlett, 2012; McConnell, 2010). The time frame may vary by issue area in most cases, but the 10-year rule established by Sabatier (1987) for the evaluation of policy change may be taken as a default if no alternative specific time frame was articulated in the policy.

While most work on policy failures has focussed on the domestic level (McConnell, 2010), and has highlighted the different political, problem and process aspects of failures, in international relations we posit two main types of policy activity which constitute distinct realms of failure. The first type concerns policy substance related specifically to the degree of attainment of the aims of a policy. For example, if an organisation attempts to create a free trade area (FTA) among its member states, the degree of FTA implementation would be the topic for evaluation. We may identify policy failures of substance in international organisations when such an objective has not been met within a specified time frame set or agreed by its member states or within the 10 -year rule as mentioned above.

The second type of policy objective is subtler and concerns organisational processes and image. This is related to the need for international organisations to reach some modicum level of agreement or a unified stance or position among member states on a course of action to pursue rather than upon the actual implementation of substantive policy content. Image, perhaps more than substance, is important for many international organisations (Knopf, 1998), especially those seeking to project an image of democracy, stability, security or the rule of law. Indeed, we often find that international organisations place a very high value on issuing joint communiqués or declarations because these statements legitimise their existence as well as individual member states' actions outside of their organisational framework (Nilsson et al., 2009; Oberthür, 2009). This emphasis on image distinguishes international organisations from many other types of organisations, including domestic states, although, too, in other spheres this same concern may sometimes be seen. It follows that we may identify policy failures of image when an international organisation does not project the image it would like.

But when and where do these failures in international organisations occur? Following Howlett (2012), we argue that 'failure' can be visible at any stage of the policy cycle, for example, when: an unattainable policy agenda is established in agenda-setting (hence leading to policy failure, or failure to reach a decision); designing a policy without investigating or understanding the causes of the problems in policy formulation (so that solutions do not match problems); failing to decide on a policy or distorting its intents during decision-making (political manipulation of policy levers for other, such as electoral, ends); failing to implement a policy effec- tively in policy implementation (deliberate or unintentional neglect or incompetence); and failing to learn due to weak policy monitoring and feedback processes in policy evaluation (mismatch between the evaluative capacity and the task an organisation faces).

It remains an outstanding empirical question at which point in their activities specific failures of substance and failures of image in international organisations occur (Chou, 2012) and why this happens. These questions are addressed in the case studies set out below. However, a major area of attention in works on policy failure (Boin \& Otten, 1996; Bovens \& t'Hart, 1995, 1996; Bovens, t'Hart, \& Peters, 2001; Deverell, 2009; Deverell \& Hansén, 2009; Moynihan, 2008, 2009) concerns the role of policy learning, or its lack, in offsetting or fulminating crises which often accompany or lead to failures of both substance and image.

Our central argument is that the features of international organisations matter in both cases: they contribute to determining the likely tendency of a particular type of policy change (substance or image) to occur and for a specific type of learning process to emerge which may be capable of correcting the problem at the present time and avoiding it reoccurring in the future.

\subsection{Policy Change and Policy Learning: Four Types of Learning Processes}

Works on policy learning in general have focussed on the governmental or non-governmental aspects of lesson-drawing, including the behaviour of specific kinds of organisations such as think tanks and research institutes involved in knowledge generation and dissemination (Ladi, 2005; Rose, 1993; Stone, 1999). These studies have often distinguished between learning about policy tools or means (Bennett \& Howlett, 1991) and learning about policy goals (Hall, 1993; Leys \& Vanclay, 2011), and have highlighted variations in the speed of change (rapid vs. slow) (Hall, 1993) which are useful distinctions that will be developed further in the context of international organisations below. Few studies, unfortunately, have focussed on how the processes of policy change and learning, or non-learning, or learning the wrong lessons can affect these processes.

This is especially true for studies of international multilateral cooperation (cf. Gallarotti, 1991). International organisations in fact have rarely been examined from a learning perspective, especially after an observable failure, and thus constitute a new venue for research into the subject and its consequences. In this context, works by Streeck and Thelen (2005) in comparative political studies provide a useful typology of policy change processes which can be linked to several key dimensions of the subject to help better situate the processes of image and substantive failures in international organisations described above. 
In their work, Streeck and Thelen (2005, pp. 19-30) describe four distinct modes of institutional change, which are relevant to the case of all organisations, including international ones and helpful in better understanding the role of learning in organisational change. ${ }^{3}$ These are:

1) Displacement ('the removal of existing tools and goals and the introduction of new ones'), often caused by exhaustion (gradual 'institutional breakdown');

2) Layering ('the introduction of new rules on top of or alongside existing ones within a similar goal framework');

3) Drift ('the changed impact of existing rules due to shifts in the environment'); and

4) Conversion ('the redeployment of existing institutions and instruments towards new goals').

Based on several studies which have examined how these change processes unfold in institutional and organisational contexts, we hypothesise that substantive and image failures in international organisations involve different kinds of change processes and outcomes. More specifically, we argue substantive failures typically involve layering and conversion processes affecting the policy tools employed, while image failures tend to occur through drift and displacement processes affecting policy goals (Baker, 2013; Béland, 2007; Shpaizman, 2014).

Further, looking at the kinds of activities in which international organisations are involved, we argue that the degree of difficulty in implementing trans-national cooperation depends very much on the issue area, and this is especially true when material interests, such as trade, finance, and natural resources, are involved. We thus expect substantive policy implementation which affects such interests directly, to be cautious, slow, and long-term. Image change, on the other hand, is less likely to involve such actors and hence can be much more abrupt. This is especially the case given the zerosum and veto-laden consensus styles of decision-

${ }^{3}$ Exhaustion and displacement are two closely linked processes that are difficult to empirically distinguish in cases of international cooperation and hence are treated here as one type (as do Mahoney \& Thelen, 2010). making practised by most international organisations. We juxtapose the different processes and speeds of change set out above to arrive at the typology of international organisational change set out in Table 1.

This begs the questions of how these kinds of failures are related to (non)learning. We expect to find different learning processes underway in different organisations depending on the kinds of change processes occurring.

Specifically, we expect substantive learning in layering processes to focus on marginal changes to instruments and in conversion processes to be linked to the ideational or ideological aspects of tool use. This is because an organisation when facing a slow and low level substantive failure tends to continuously aim to achieve the original goal by deploying a new instrument or refining an old one. With a more rapid and higher level of substantive failure, the organisation faces a situation in which policy progress is deemed to be essential and crucial for achieving objective and learning, in this instance, is likely to be associated with deliberation and debate not only about instrument calibrations but also about the ultimate ability of different types of policy instruments to achieve policy goals.

On the other hand, in image change situations we expect to see drift processes linked to a focus on the contextual aspects of policy goals and displacement processes to involve analysis of both goals and means in all their dimensions. Specifically, learning in drift processes depends on actors becoming aware of the changing organisational context and environment and their divergence with agreed policy goals. It is likely to be a slow process because of the initial divide (i.e. disagreements between actors) that has led to image failure in the first instance. With the recoverable degree of image failure, learning in a drift process would see an organisation attempting to adjust its original policy goals to a new environment despite its changed impact. The organisation's foremost concern is to maintain its image or to project unity in public rather than to substantially achieve the goal. With an unrecoverable degree of image failure, learning will encompass both the original organisational or policy goals set out and the means to achieve them.

This chain of failure, change processes and learning subjects and types is set out in Table 2.

Table 1. Taxonomy of international policy change.

\begin{tabular}{llll}
\hline Type of Failure & Key Change Element & Typical Change Process & Speed of Change \\
\hline Substantive & Instruments & Layering & Slowest \\
& & Conversion & More Rapid \\
\hline Image & Goals & Drift & Slower \\
& & Displacement & Most Rapid \\
\hline
\end{tabular}


Table 2. Learning and types of policy failure.

\begin{tabular}{llll}
\hline Type of failure & $\begin{array}{l}\text { Key change elements \& } \\
\text { speed characteristics }\end{array}$ & Associated learning process & Learning subjects \& type \\
\hline Substantive & Instruments, Slow & Layering \& Learning & Instruments, Marginal \\
& Instruments, Rapid & Conversion \& Learning & Instruments, Ideational \\
\hline Image & Goals, Slow & Drift \& Learning & Goals, Contextual \\
& Goals, Rapid & Displacement \& Learning & Goals and Means, Analytical \\
\hline
\end{tabular}

\section{Testing the Framework: Two Case Studies of Policy Failures in Regional Organisations}

Applying this framework to two case studies of policy change beyond the national level allows us to test these hypotheses in the context of regional organisations and policy development. In this section, we compare policy failures in two such organisations to see if the expected relationships between failure types and learning processes hold. The cases of ASEAN and the EU are used to consider one case each of substance and image failure. We selected ASEAN and the EU as our cases because both have successfully survived the Cold War and the post-Cold War era, yet they are often criticised for their inability to further regional cooperation in Asia and Europe beyond the maintenance of the general status quo or, indeed, as is the case of postBrexit EU, even the status quo. At the same time, ASEAN and the EU are also two cases exhibiting different organisational traits. For instance, the EU is one of the most sophisticated supranational bureaucracies in the world, with entities such as the European Commission, Parliament, and a Court of Justice designed to exercise independent executive, legislative, and judiciary powers across multiple policy sectors. By contrast, ASEAN is far less institutionalised and has no entities as comparatively bureaucratised and powerful as the EU's. Their shared external perception and distinct organisational characteristics provide a comparative entry point from which to examine the relationship between organisational features, failure, and learning in general.

\subsection{Dealing with ASEAN Image Failure: Failing to Be United and Learning to Drift}

At its inception in 1967, ASEAN never envisioned itself engaging with security affairs, but in the post-Cold War period, it made two significant changes: inclusion of a security agenda and establishment of security-oriented entities with external powers' participation, such as the ASEAN Regional Forum (ARF) and East Asia Summit (EAS). ASEAN then began to confront security issues in the region.

Admittedly, partly due to ASEAN's non-binding nature, and partly due to member states' differing security interests within and beyond the region (cf. Koga, 2010a, 2010b), ASEAN's capability to manage these is- sues with any substance is significantly limited and it is often called a 'talk shop'. Nevertheless, through its numerous dialogues, ASEAN produces joint statements and declaration, and consciously tries to project an image of its 'unified' stance to the international community. ASEAN is thus an image-based organisation in the security field, and one of its broader objectives is to maintain the image of a 'unified' stance towards regional political and security issues.

ASEAN thus encountered a serious image failure when its members did not adopt a joint communiqué on the South China Sea issue in 13 July 2012. This failure negatively impacted its image of organisational coherence as ASEAN had consistently issued joint communiqués every year since 1967 following its annual foreign ministerial meetings (AMM). This was done regularly, no matter how unsubstantial the content of the communiqué became. It was hence a symbol of ASEAN solidarity and the organisation carefully reproduced such an image each year since its inception. Therefore, the failure to issue one in 2012 was seen as a significant indicator of discord and dysfunction within the organisation.

The main cause of this failure stemmed from internal disagreement between the Philippines and Cambodia in ironing out the wording about territorial disputes in the South China Sea to be included in the joint communiqué. ASEAN's basic political stance over the territorial disputes in the South China Sea can be summarised as 'maintaining neutrality and regional stability'. ASEAN would not support any claims regarding these territorial disputes. Yet ASEAN was concerned about a potential disruption of the safety of sea lines of communication (SLOCS) caused by claimant states' skirmishes and conflicts in the area, and thus it was willing to facilitate dialogues for their peaceful resolution. With this posture, ASEAN created the 'Declaration on the Conduct of Parties in the South China Sea' (DoC) in 2002 as a guideline of actions over the area. In addition, ASEAN and China discussed the creation of a Code of Conduct $(\mathrm{CoC})$ to legally constrain claimant states' behaviour.

In this context, the tension between the Philippines and China over one particular disputed territory, the Scarborough Shoal in the South China Sea, heightened from 8 April 2012, when the Philippines' naval ships attempted to arrest eight Chinese fishery boats staying 'too' close to the Shoal. In response, China immediately 
dispatched two patrol ships from the Bureau of Fisheries Administration and blocked the Philippines' naval ships to prevent them from arresting Chinese fishery boats, resulting in a two-month maritime stand-off.

Reacting to this, the Philippines proposed to include a condemnation statement against China into the 2012 AMM joint communiqué. However, this triggered an internal division within ASEAN. Cambodia's Prime Minister Hun Sen emphasised the importance of reducing tensions with China and a code of conduct in the South China Sea ("Hun calls for ASEAN South China Sea code," 2012), insisting that a naming and shaming strategy would only exacerbate the situation ("ASEAN agrees not to mention territorial row," 2012; "Vietnam, Philippines 'bullying' ASEAN over sea conflict," 2012). Laos, Myanmar, and Thailand supposedly supported Cambodia's position (Manthorpe, 2012) and the Cambodian Ambassador to Singapore, Sin Serey, reiterated this position in August by way of accusing the Philippines for its failure to reduce tension in the region ("S. China Sea code of conduct in the works," 2012). The Philippines then criticised Cambodia as being too close to China and promoting Chinese interests ("Naval dispute sinks ASEAN summit talks," 2012; "Xinhua interviews Chinese deputy foreign minister," 2012). It insisted the recent development in the South China Sea would affect the stability in Southeast Asia and the members' interests were at stake. According to the Philippines' Foreign Undersecretary, Erlinda Basilio, Singapore, Indonesia, Malaysia, Thailand, and Vietnam supported this view (Basilio, 2012). ASEAN was decisively split on the matter, resulting in non-issuance of a joint communiqué.

The failure to issue a joint communiqué at AMM raised the question of ASEAN's credibility. Although ASEAN was generally expected to produce an abstract statement to project its image of unity, it became increasingly clear that when there was a strong conflict of interest among the member states, ASEAN could easily become dysfunctional. Several ASEAN members expressed this concern and argued that, if ASEAN failed to develop a collective position, it would lose influence over regional great powers. These included Singapore's Foreign Minister K. Shanmugan and Malaysia's Foreign Minister Anifah Aman (Ghosh, 2012; "South China Sea dispute could affect ASEAN's image," 2012; "Unity before China urged," 2012).

Several ASEAN member states and secretary general also perceived this risk and attempted to restore its organisational image ("Maritime disputes trouble Asian bloc," 2012; "S. China Sea code of conduct in the works," 2012). This effort led ASEAN members to gradually avoid in-depth, contentious discussions regarding the South China Sea issue within AMM, while keeping other unrelated agendas on the table. Instead, they attempted to use different ASEAN venues for discussing the issue. In July 2012, while failing to issue a joint communiqué, ASEAN foreign ministers agreed to man- date ASEAN senior officials to meet with representatives from China for further discussions on the $\mathrm{CoC}$ ("ASEAN adopts common stand," 2012). Also, in November 2012, when the ASEAN summit and related forums were held, the Philippines invited the United States to discuss the matter ("ASEAN seeks to calm sea disputes," 2012). International and regional powers, such as the United States and Australia, showed their willingness to discuss the South China Sea issue because it was important for the security of SLOCs and regional stability ("Obama tackles Wen on sea feud," 2012a; "PM pushes China on maritime claims," 2012b). Given this, the ASEAN members moved its designated venue for this issue from the AMM to other forums that included great power members.

In sum, facing this policy failure at the AMM, ASEAN did not reform the AMM as an organisational entity. An image-based organisation's policy failure could have an enormous impact and produce rapid changes, leading to change through displacement. But this did not happen. The ASEAN case instead illustrates that no organisational change followed the policy failure and rather highlighted a particular aspect of learning and drift. That is, while the objective of ASEAN's dispute settlement practice remained the same, shifts in its environment made it difficult to sustain existing practices. However, this became possible when ASEAN deferred the matter to a satellite venue (the EAS) and the organisation was able to conduct a 'run-around'-buying time for acceptable solutions to present themselves, or pretending to do so. This allowed the AMM to return to its status quo ante, which in turn contributed to the continuation of projecting an image of ASEAN unity, ameliorating the earlier failure. ${ }^{4}$

\subsection{Dealing with EU Substance Failure: Failing to Attract the 'Best-and-Brightest'?}

The ASEAN case shows how particular kinds of learning are related to image-based policy issues and failures. The second case presented here, on EU cooperation on labour migration, illustrates the learning dynamics occurring in a substantive issue area. ${ }^{5}$

\footnotetext{
${ }^{4}$ At the same time, we note this organisational 'run-around' is possible because ASEAN established several affiliated entities in the past. If none existed, ASEAN may have created a new entity to discuss the issue informally or formally, or exhibit displacement or drift. In this sense, this case illustrates that institutional change and learning are likely to depend on not only the type of organisation, but also the organisational structure, which determines the strategies that organisational actors could employ to cope with policy failure.

${ }^{5}$ The current and on-going crisis concerning asylum-seeking and undocumented migrants arriving on the shores of Europe is another excellent case for applying our proposed approach. Given the space limitation, we are unable to include both the asylum-seeking and labour migration as cases in this sub-
} 
Migration cooperation has been contentious since the very beginning of the EU (see Chou, 2009, for an overview) and has become much more so in the very recent past. Indeed, the original EU members never intended to engage in this area of cooperation and only did so to achieve a core integration objective: the free movement of persons within the European labour force. When the EU removed internal border controls against its citizens, however, it also saw 'unwanted' secondary movement of asylum applicants and unauthorised migration. Hence, the first measures and policies adopted in the migration field revolved around how to strengthen the common external borders through, for example, creating a common visa regime, signing readmission agreements with non-EU countries (the 'Neighbourhood' and beyond), and the mutual recognition of asylum status. It was not until the adoption of the 1999 Tampere conclusions, and its subsequent re-endorsement at The Hague and Stockholm, that a more 'comprehensive' outlook entered into European policy parlance and cooperation spread to other forms of migration such as family reunification and international labour migration (Council, 1999). ${ }^{6}$

The Commission presented the first Tampere labour migration policy proposal in 2001 with a deadline of 1 May 2004 for its completion. This measure-the Council directive on the conditions of entry and residence of third-country nationals for the purpose of paid and self-employed economic activities (Commission, 2001)-had it been adopted, would introduce a set of directly binding common conditions under which a joint residence and work permit would be issued to a foreign worker. The policy idea was that, if the applicants satisfied the requirements for obtaining work permits, there was no need to repeat the bureaucratic process for obtaining the residence permit.

This proposal is an excellent example of an outright substantive and procedural failure within an international organisation. The EU member states' migration ministers, sitting in the configuration of the Council of Ministers, considered the Commission's proposal intensely throughout 2002, but little progress was made. The lack of policy progress was due to national opposition; member states refused to discuss the proposal on the grounds that there was no EU legal basis for the use of this policy instrument (Council, 2003). When the

section. However, we would like to point out that the EU's failure in fostering a holistic labour migration policy to apply to all skill levels is not entirely unrelated to the current crisis revolving around asylum-seeking.

${ }^{6}$ The organisational features of EU labour migration policy cooperation have evolved dramatically over the years: from intergovernmental consensus-seeking decision-making to the 'ordinary' procedure under the Lisbon Treaty (see Cerna \& Chou, 2014, for how this led to different outcomes in the labour migration field). The member states, however, still have the final say about admission numbers for economic migrants.
Council refused to negotiate, the Commission withdrew the proposal in March 2006.

What kind of policy failure was this? To begin, it is clear this failure is one of substance since a substantive policy (i.e. an EU directive) failed to be adopted or implemented. We need, however, to examine how the Commission prepared for its 'comeback' in the labour migration domain in order to be more precise about how and why the original 2001 proposal had failed. Even before it withdrew its proposal in 2006, the Commission officials responsible for the dossier realised that they needed to adopt another approach for labour migration issues (Chou, 2009). These Commission officials prepared for the new approach firstly by carrying out informal discussions with the member states. In these talks the Commission identified what could be the EU's added-value in labour migration regulation (Chou, 2009) and then in January 2005 issued a Green Paper on 'managing economic migration', which asked whether there was a need to set out common EU instruments for admitting foreign workers (Commission, 2005). Based on the responses from the public and stakeholder groups, the Commission concluded that the majority of the respondents supported a labour migration policy at the regional level.

The Commission's preparations tell us that the initial substantive policy failure was the result of failure at three different policy stages: agenda-setting (the Commission pushed an unattainable policy agenda by proposing the directive for a joint residence and work permit); policy formulation (the Commission failed to take into consideration what the member states actually wanted in terms of cooperation in the labour migration field); and decision-making (the member states blocked the Commission proposal by arguing that there was no treaty basis for this initiative).

By identifying where it had failed, the Commission was able to learn and re-launch the momentum in EU labour migration policy cooperation. For instance, the responses from the Green Paper gave the Commission popular legitimacy in setting out a new policy agenda for labour migration. By informally soliciting the member states' inputs to the labour migration policy agenda, which was crucial for policy formulation, the Commission was able to parse out in what the member states were primarily interested: an EU measure that would address a specific subset of migrants - the highly skilled. By contrast, the failed 2001 directive addressed all categories of migrant workers and sought to set out their rights once they were admitted to the EU.

The Commission's learning and careful preparation following its original failure thus led to the successful adoption of the first of several EU labour migration measures. ${ }^{7}$ The failed 2001 proposal delimited how la-

7 In October 2007, the Commission presented the newest EU initiative in labour migration: the EU Blue Card (formally known 
bour migration policy cooperation would be understood at the supranational-level: EU policies in this area would firstly address the highly skilled before others would be considered. This is thus an example of learning through conversion in which EU policy discussions on labour migration would be strategically redeployed to relate in the first instance to the recruitment of foreign talent, with existing and subsequent policy instruments (such as the Scientific Visa and the EU Blue Card) configured to achieve this end before other labour migration measures were considered and adopted.

\section{Analysis, Conclusions and Ways Forward}

In this article, we set out an analytical framework that allows us to better understand the nature of policy failures in international organisations and the mechanisms, such as learning, by which they occur and may be overcome. Our goal was to identify and connect specific failure types with the likely modes of institutional change that could ultimately lead to organisational and policy transformation, and to better understand their linkages with modes of learning. Our framework distinguished between two kinds of policy failures associated with the workings, outputs and outcomes of international organisations: failure in substance and failure in image. We hypothesised that these different types of failure would exhibit different

as the directive on the conditions of entry and residence of third-country nationals for the purposes of highly qualified employment) (Council, 2009). While this proposal 'fit' what the member states favoured, there was still considerable disagreement among them from the outset. For instance, Cerna and Chou (2014) tell us that there were, in the main, five sets of objections. Similar to the failed 2001 proposal, several member states rejected the proposal on the grounds of 'sovereignty' and referenced The Hague programme's proclamation that 'the determination of volumes of admission of labour migrants is a competence of the Member States' (Council, 2004). The second objection came from the new member states (Czech Republic and Slovakia) and revolved around the transition period placed on the free movement of their nationals: these member states could not support recruiting foreign talent when their citizens were barred from accessing the other member states' labour markets. The third set of objections concerned the definition of highly skilled migrants (there were none) and salary threshold the applicant must evidence (how much higher should it be in comparison to those of EU workers?). The fourth was about lowering the admissions barriers to young professionals. And the fifth was about the rights to which Blue Card holders would be entitled. When the policy proposal was finally adopted in 2009, it embodied nearly the lowest-common-denominator: most of the rights for the admitted highly skilled migrants were removed or moved up to the preamble (which meant that the articles were guiding and not binding); admissions requirements were made more restrictive (e.g. the salary threshold the highly skilled migrant needed to earn would be higher than the average EU workers). characteristics in terms of speed and the types of learning which would allow them to be overcome.

We argued that different modes of institutional change (layering, drift, conversion, and displacement) identified in earlier studies of long-term institutional development and change can be connected to substance-based and image-based organisations and to policy learning. Organisational features such as relative veto likelihood and the overall material capabilities of an organisation in policy implementation (i.e. its ability to realise or adopt a specific policy position) shape what kind of policy failure, image or substance, is likely to occur and specific learning types can be linked to specific change processes common in each case. We expected substantive learning in layering processes to focus on marginal changes to instruments and in conversion processes to be linked to the ideational or ideological aspects of tool use. In learning situations for image-based organisations, we expected to see drift processes linked to a focus on the contextual aspects of policy goals and displacement processes to the analysis of both goals and means in all their dimensions.

We applied this framework to two instances of policy failure in two regional organisations-ASEAN and the EU-one a case of image failure and the other of substance, and found the following. As the EU case shows, policy failure in substance may be quite subtle and nuanced in dealing with policy tool calibrations and uses and may take years to become visible, both empirically and in terms of the judgments of relevant policy actors (McConnell, 2010). On the other hand, as anticipated, the ASEAN case illustrates, policy implementation where image is of central aim is generally less nuanced and appears more quickly. This is because, unlike policy substance, organisational image is a straightforward political act, and once the members of an organisation agree to establish a cooperative scheme by producing joint declarations or statements, it more or less automatically produces a positive image of their political unity (May, 1992, 1999). Ipso facto, image failure also occurs quickly following a failed decision. ${ }^{8}$

We found by moving the controversial issue out of the AMM and into satellite venues where discussions are less prominent, ASEAN members were able to avoid drastic changes and damages to its reputation. The drift process followed in this case and the specific method followed-organisational 'run-around'-is a form of incremental transformation and manifestations

\footnotetext{
8 This is unlike the domestic situation where there is usually a state monopoly on decision-making power, and the state does not have to consider other states' interests in most circumstances, so that image concerns are largely secondary to considerations of substantive failure (Howlett, 2012; Scharpf, 1988).
} 
of learning in international organisations facing this kind of failure and should be a subject of more detailed inquiry and investigation in future works.

Our EU case study, on the other hand, is an example of how a policy failure in substance can be overcome through learning and lesson-drawing. We found the failure to adopt an EU directive on a joint residence and work permit for foreign workers during the Tampere period to have been reconfigured to allow the utilisation of existing tools related primarily to the recruitment and regulation of highly skilled migrants. What the EU case revealed is that there is an operational policy cycle of substantive failure and political learning (on the part of the European Commission) that is involved in the daily functions of regional organisations like the EU. When the Commission officials realised that their 2001 proposal was unlikely to be adopted, they embarked on a learning exercise of soliciting and fine-tuning through continuous dialogue with national migration ministers that helped shape the outcome of its second labour migration policy proposal. This is an example of institutional change exhibiting conversion change patterns, again as our framework anticipated.

Thus both cases have shown our analytical framework to be a useful starting point to examining policy failures in international organisations and how they can be overcome through learning. It also illustrates how several aspects of the framework should be further refined. This includes issues such as the utility of organisational 'run-around' to avoid failure, the issue of organisational capacity related to substantive goal achievement and re-definition as well as the conditions of the success or failure of policy learning as both our cases are examples of successful learning. However, better defining the object of attention-policy failures in international organisations - in both substantive and image terms, and linking these two types of failure to different learning styles and processes is a significant step forward in better understanding, and avoiding, policy failures beyond the national level, a subject heretofore rarely examined in the policy failure literature and not well understood in the literature on international relations.

\section{Acknowledgement}

We would like to thank the three reviewers and the editors of this special issue for their insightful comments and suggestions for improving this article. Meng-Hsuan Chou is grateful for the support from NTU Singapore's NAP Start-Up Grant for this research. As always, all errors remain our own.

\section{Conflict of Interests}

The authors declare no conflict of interests.

\section{References}

Argyris, C., \& Schön, D. A. (1978). Organizational learning: $A$ theory of action perspective. Reading: AddisonWesley.

ASEAN adopts common stand to negotiate South China Sea code with China. (2012, July 9). Japan Economic Newswire. Retrieved from http://english.kyodonews. jp

ASEAN agrees not to mention territorial row. (2012, July 14). Weekend Australian. Retrieved from http:// www.theaustralian.com.au/life/weekend-australianmagazine

ASEAN seeks to calm sea disputes China doesn't want issue raised. (2012, November 18). The Nation. Retrieved from http://www.nationmultimedia.com

Baker, A. (2013). The gradual transformation? The incremental dynamics of macroprudential regulation. Regulation \& Governance, 7(4), 417-434.

Basilio, E. (2012, July 19). Why there's no ASEAN joint communiqué. Philippines Daily Inquirer. Retrieved from http://globalnation.inquirer.net/44771/whythere\%E2\%80\%99s-no-asean-joint-communique

Béland, D. (2007). Ideas and institutional change in social security: Conversion, layering and policy drift. Social Science Quarterly, 88(1), 20-38.

Bennett, C. J., \& Howlett, M. (1991). The lessons of learning: Reconciling theories of policy learning and policy change. Policy Sciences, 25(3), 275-294.

Boin, R. A., \& Otten, M. H. P. (1996). Beyond the crisis window for reform: Some ramifications for implementation. Journal of Contingencies and Crisis Management, 4(3), 149-161.

Borrás, S., \& Højlund, S. (2015). Evaluation and policy learning: The learners' perspective. European Journal of Political Research, 54(1), 99-120.

Bovens, M., \& t'Hart, P. (1995). Frame multiplicity and policy fiascoes: Limits to explanation. Knowledge and Policy, 8(4), 61-83.

Bovens, M., \& t'Hart, P. (1996). Understanding policy fiascoes. New Brunswick, NJ: Transaction Press.

Bovens, M., t'Hart, P., \& Peters, B. G. (Eds.). (2001). Success and failure in public governance: A comparative analysis. Cheltenham: Edward Elgar.

Busenberg, G. (2001). Learning in organizations and public policy. Journal of Public Policy, 21(2), 173-189.

Cerna, L., \& Chou, M. H. (2014). The regional dimension in the global competition for talent: Lessons from framing the European Scientific Visa and Blue Card. Journal of European Public Policy, 21(1), 76-95.

Chou, M. H. (2009). Historical institutionalism and the evolution of European Union's asylum and immigration acquis (1992-2004) (Unpublished Doctoral dissertation). Centre for International Studies, University of Cambridge, United Kingdom.

Chou, M. H. (2012). Constructing an internal market for research through sectoral and lateral strategies: Lay- 
ering, the European Commission and the fifth freedom. Journal of European Public Policy, 19(7), 10521070.

Commission. (2001). Proposal for a Council Directive on the conditions of entry and residence of third-country nationals for the purpose of paid employment and self-employed economic activities (386 final). Brussels, Belgium: European Commission.

Commission. (2005). Green Paper on an EU approach to managing economic migration (811 final). Brussels, Belgium: European Commission.

Council. (1999). Tampere European Council Conclusions, 15-16 October 1999. Brussels, Belgium: Council of Ministers.

Council. (2003). Outcome of Proceedings from the Working Party on Migration and Expulsion on 22 November 2003 for the Proposal for a Council Directive on the conditions of entry and residence of third-country nationals for the purpose of paid employment and self-employed economic activities (13954/03). Brussels, Belgium: Council of Ministers.

Council. (2004). The Hague Programme: strengthening freedom, security and justice in the European Union (16054/04). Brussels, Belgium: Council of Ministers.

Council. (2009). Council Directive of 25 May 2009 on the conditions of entry and residence of third-country nationals for the purposes of highly qualified employment (2009/50/EC). Brussels, Belgium: Council of Ministers.

Deverell, E., \& Hansén, D. (2009). Learning from crises and major accidents: From post-crisis fantasy documents to actual learning in the heat of crisis. Journal of Contingencies and Crisis Management, 17(3), 143145.

Deverell, E. (2009). Crises as learning triggers: Exploring a conceptual framework of crisis-induced learning. Journal of Contingencies and Crisis Management, 17(3), 179-188.

Dodgson, M. (1993). Organizational learning: A review of some literatures. Organization Studies, 14(3), 375394.

Dunlop, C. A., \& Radaelli, C. M. (2013). Systematising policy learning: from monolith to dimensions. Political Studies, 61, 599-619.

Etheredge, L. S., \& Long, S. L. (1981). Government learning: An overview. In S. L. Long (Ed.), The handbook of political behavior (pp. 1-50). New York: Plenum.

Etheredge, L. S., \& Short, J. (1983). Thinking about government learning. Journal of Management Studies, 20(1), 41-58.

Gallarotti, G. M. (1991). The limits of international organizations: Systematic failure in the management of international relations. International Organization, 45(2), 183-220.

Ghosh, N. (2012, July 14). ASEAN meeting fails to reach agreement on joint statement. The Straits Times. Retrieved from http://www.straitstimes.com
Hall, P. A. (1993). Policy paradigms, social learning and the state: The case of economic policy making in Britain. Comparative Politics, 25(3), 275-296.

Howlett, M. (2012). The lessons of failure: Learning and blame avoidance in public policy-making. International Political Science Review, 33(5), 539-555.

Huber, G. P. (1991). Organization learning: The contributing processes and the literatures. Organization Science, 2(1), 88-115.

Hulme, R., \& Hulme, M. (2012). Policy learning? Crisis, evidence and reinvention in the making of public policy. Policy \& Politics, 40(4), 473-489.

Hun calls for ASEAN South China Sea code. (2012, July 10). The Australian. Retrieved from http://www. theaustralian.com.au

Jachtenfuchs, M. (1996). International policy-making as a learning process? The European Union and the greenhouse effect. Aldershot: Ashgate.

Knopf, J. W. (1998). The importance of international learning. Paper presented at the Annual Meeting of the American Political Science Association, Boston, USA.

Koga, K. (2010a). Competing institutions in East Asian regionalism: ASEAN and the regional powers. Issues \& Insights, 10(23), i-29.

Koga, K. (2010b). The normative power of the 'ASEAN Way'; Potentials, limitations, and implications for East Asian regionalism. Stanford Journal of East Asian Affairs, 10(1), 80-95.

Ladi, S. (2005). Globalisation, policy transfer and policy research institutes. Cheltenham: Edward Elgar.

Leys, A. J., \& Vanclay, J. K. (2011). Social learning: A knowledge and capacity building approach for adaptive co-management of contested landscapes. Land Use Policy, 28(3), 574-584.

Mahoney, J., \& Thelen, K. (2010). A theory of gradual institutional change. In J. Mahoney \& K. Thelen (Eds.), Explaining institutional change: Ambiguity, agency, and power (pp. 1-37). Cambridge: Cambridge University Press.

Manthorpe, J. (2012, July 23). ASEAN patches up rift over territorial disputes with Beijing. The Vancouver Sun. Retrieved from http://vancouversun.com

Maritime disputes trouble Asian bloc. (2012, August 28). The Washington Post. Retrieved from https://www. washingtonpost.com

May, P. J. (1992). Policy learning and failure. Journal of Public Policy, 12(4), 331-354.

May, P. J. (1999). Fostering policy learning: A challenge for public administration. International Review of Public Administration, 4(1), 21-31.

McConnell, A. (2010). Policy success, policy failure and grey areas in-between. Journal of Public Policy, 30(3), 345-362.

Moynihan, D. P. (2008). Learning under uncertainty: Networks in crisis management. Public Administration Review, 68(2), 350-365. 
Moynihan, D. P. (2009). From intercrisis to intracrisis learning. Journal of Contingencies and Crisis Management, 17(3), 189-198.

Naval dispute sinks ASEAN summit talks. (2012, July 14). The Daily Gazette. Retrieved from http://www. dailygazette.com

Nilsson, M., Pallemaerts, M., \& von Homeyer, I. (2009). International regimes and environmental policy integration: Introducing the Special issue. International Environmental Agreements: Politics, Law and Economics, 9(4), 337-350.

Obama tackles Wen on sea feud. (2012a, November 21). The Australian. Retrieved from http://www.the australian.com.au

Oberthür, S. (2009). Interplay management: Enhancing environmental policy integration among international institutions. International Environmental Agreements: Politics, Law and Economics, 9(4), 371-391.

PM pushes China on maritime claims. (2012b, November 21). The Australian. Retrieved from http://www.the australian.com.au

Radaelli, C. M., \& Dunlop, C. A. (2013). Learning in the European Union: Theoretical lenses and metatheory. Journal of European Public Policy, 20(6), 923940.

Rose, R. (1993). Lesson-drawing in public policy: A guide to learning across time and space. Chatham: Chatham House Publishing.

Rose, R. (2005). Learning from comparative public policy. London: Routledge.

S. China Sea code of conduct in the works. (2012, August 9). The Straits Times. Retrieved from http://www. straitstimes.com

Sabatier, P. (1987). Knowledge, policy-oriented learning, and policy change. Knowledge: Creation, Diffusion, Utilization, 8(4), 649-692.

Scharpf, F. W. (1988). The joint-decision trap: Lessons from German federalism and European integration. Public Administration, 66(3), 239-278.
Shpaizman, I. (2014). Ideas and institutional conversion through layering: The case of Israeli immigration policy. Public Administration, 92(4), 1038-1053.

Shrivastava, P. (1983). A typology of organizational learning systems. Journal of Management Studies, 20(1), 7-28.

South China Sea dispute could affect AESAN's image. (2012, July 12). Channel News Asia. Retrieved from http://www.channelnewsasia.com

Stone, D. (1999). Learning lessons and transferring policy across time, space and disciplines. Politics, 19(1), 5159.

Stone, D. (2001). Learning lessons, policy transfer and the international diffusion of policy ideas. CSGR Working Paper, 69(1), 1-41.

Streeck, W., \& Thelen, K. (2005). Introduction: Institutional change in advanced political economies. In W. Streeck \& K. Thelen (Eds.), Beyond continuity: Institutional change in advanced political economies (pp. 139). Oxford: Oxford University Press.

Thomas, G. B. (1999). External shocks, conflict and learning as interactive sources of change in U.S. security policy. Journal of Public Policy, 19(2), 209-231.

Unity before China urged. (2012, August 13). The Australian. Retrieved from http://www.theaustralian. com.au

Van der Knaap, P. (1995). Policy evaluation and learning. Evaluation, 1(2), 189-216.

Vietnam, Philippines 'bullying' ASEAN over sea conflict. (2012, July 12). Japan Economic Newswire. Retrieved from http://english.kyodonews.jp

Xinhua interviews Chinese deputy foreign minister on ties with ASEAN. (2012, August 8). BBC Monitoring Asia Pacific-Political. Retrieved from http://www. bbc.co.uk/monitoring

Zarkin, M. J. (2008). Organisational learning in novel policy situations: Two cases of United States communications regulation. Policy Studies, 29(1), 87-100.

\section{About the Authors}

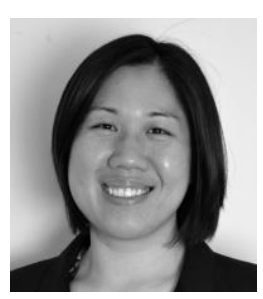

Meng-Hsuan Chou is Nanyang Assistant Professor in the Public Policy and Global Affairs Programme at Nanyang Technological University (NTU), Singapore.

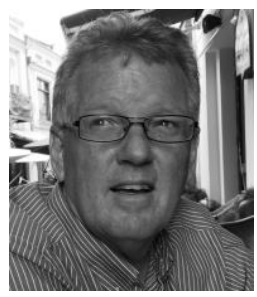

Michael Howlett is Burnaby Mountain Chair in the Department of Political Science at Simon Fraser University, Canada, and Yong Pung How Chair Professor in the Lee Kuan Yew School of Public Policy at the National University of Singapore. 


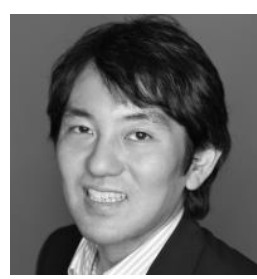

Kei Koga is Assistant Professor in the Public Policy and Global Affairs Programme at Nanyang Technological University (NTU), Singapore. 